\title{
Effect of Copper and Nickel on the Transformation Kinetics of Austempered Ductile Iron
}

\author{
Marcin Górny, Edward Tyrała, and Hugo Lopez
}

\author{
(Submitted April 15, 2014; in revised form June 30, 2014; published online July 23, 2014)
}

\begin{abstract}
The kinetics of reaction occurring during the austempering treatment of ductile iron (DI) containing different additions of $\mathrm{Cu}$ and $\mathrm{Ni}$ was investigated in this work. DI bars were heat treated in an instrumented dilatometer in order to follow the exhibited transformation kinetics. The dilatometric results indicated that the addition of $\mathrm{Cu}$ alone did not have a significant effect on the incubation times for the austempering transformation. Also, the addition of both, $\mathrm{Cu}$ and $\mathrm{Ni}$ resulted in a significant effect on reducing the transformation rates. It was found that the austempering process is characterized by two clearly distinguished transformation stages. In the initial stage, the addition of $\mathrm{Cu}$, and to a greater extent, additions of both $\mathrm{Cu}$ and $\mathrm{Ni}$ led to reductions in the transformation rates shifting the maximum transformation rate values toward longer times. The outcome of this work indicates that during the first stage of austempering, nucleation of the ferrite plates occurs via a diffusionless mechanism while their growth is diffusion controlled. Moreover, after the maximum in the transformation rate has been reached, the growth of ferrite plates becomes dominant with the rate-limiting step becoming the diffusion of $C$ into the surrounding austenite. A qualitative model for the austempering transformation is proposed in this work to account for the experimental observations.
\end{abstract}

Keywords austempered ductile iron, dilatometry, phase transformations

\section{Introduction}

Austempered ductile iron (ADI) is ductile iron, which is subject to heat treatment in order to achieve an optimal combination of strength, ductility, and toughness (Ref 1). The relatively low production costs and weight saving potential of ADI makes it an important alternative to steel and aluminum alloys. Castings made of austempered ductile iron possess superior relative mechanical properties (property/density) than aluminum alloys (Ref 5,6). ADI is an excellent material to be used in diverse applications including, the automotive and agricultural industries (Ref 1-6). Among the main factors that influence the quality of ductile iron castings are the chemical composition, cooling rate, liquid treatment, as well as implemented heat treatments. In commercial practice, Ni (up to 2.0 wt.\%) and $\mathrm{Cu}$ (up to 1.5 wt.\%) are common alloying elements for the production of high strength ADIs with relatively high hardenability and ductility.

The process of heat treatment of ADI consists of austenitisation in the range of $850-950{ }^{\circ} \mathrm{C}$, where the as-cast matrix (pearlitic, ferritic) transforms into austenite and there is also an enrichment of austenite with carbon from the graphite nodules.

Marcin Górny and Edward Tyrala, AGH-University of Science and Technology, Reymonta Str. 23, 30-065 Kraków, Poland; and Hugo Lopez, University of Wisconsin-Milwaukee (UWM), 784, Milwaukee, WI 53201. Contact e-mail: mgorny@agh.edu.pl.
Austenitization is followed by rapid cooling to the range of 250-450 ${ }^{\circ} \mathrm{C}$ with isothermal holding for a time required for the transformation to take place. A two-stage phase transformation takes place in ADI (Ref 7-12). In the first stage, ferrite plates grow into the austenite grains. This is associated with carbon rejection from the ferrite plates into austenite (Ref 13). After the enrichment of austenite of up to $1.8-2.2 \%$ of carbon, this austenite is thermally and mechanically stable without the formation of martensite. After prolonged times of austempering, high carbon austenite eventually decomposes into bainite (ferrite and iron carbides) in to its second stage of reaction. Martensite and carbides are undesirable from the point of view of the mechanical properties of ADI (Ref 8, 14-16). The final ADI microstructure thus consists of graphite nodules in a matrix of ferrite plates and high carbon austenite. To understand the ADI reaction kinetics, one has to monitor the phase transformation (Ref 17).

From the microstructural point of view, the austenite fraction and the carbon content in austenite are typically controlled by implemented heat treatments. In particular, the appropriate austenitizing and austempering temperatures and times are strongly influenced by the alloying elements and their relative amounts. Both, $\mathrm{Cu}$ and Ni possess fcc structures and are highly soluble in austenite. These alloying elements in proper amounts lead to adequate austemperability, but their presence also influences austempering kinetics. Consequently, there is a modification in the exhibited microstructures, and the resultant mechanical properties. In ADI, the isothermal decomposition of austenite during austempering is of the outmost importance from the viewpoint of the exhibited microstructure. From published literature (Ref 18-21), there is limited information on the initial stages of ferrite plate nucleation and their subsequent growth during austempering. Hence, the actual mechanisms associated with ausferrite reaction have not yet been clearly disclosed. Hence, in this work the initial stages associated with 
the austempering reactions were investigated. Experimentally, dilatometry in combination with microstructural determinations was employed to characterize the isothermal austenite decomposition. This work also considers the effect of $\mathrm{Cu}$ and $\mathrm{Ni}$ additions on the austempering kinetics of ductile cast iron.

\section{Experimental}

The experimental melts were prepared in a $15 \mathrm{~kg}$ capacity crucible using an electrical induction furnace of intermediate frequency. The furnace charge consisted of Sorelmetal (High Purity Pig Iron: $4.46 \% \mathrm{C}, 0.132 \% \mathrm{Si}, 0.01 \% \mathrm{Mn}, 0.006 \% \mathrm{~S}$, $0.02 \% \mathrm{P})$, technically pure silica, Fe-Mn, steel scrap, copper, and nickel. After melting at $1763 \mathrm{~K}\left(1490^{\circ} \mathrm{C}\right)$, the liquid metal was held for 2 min followed by spheroidization and inoculation operations using a bell method. 1.5 wt.\% of a Fe-Si-Mg $(6 \% \mathrm{Mg})$ foundry alloy was used for spheroidization, while 0.5 wt. $\%$ of Foundrysil $(73-78 \% \mathrm{Si}, 0.75-1.25 \% \mathrm{Ca}, 0.75-$ $1.25 \% \mathrm{Ba}, 0.75-1.25 \% \mathrm{Al}$, Fe: balance) was used for inoculation purposes. The cast iron was poured at $1673 \mathrm{~K}\left(1400{ }^{\circ} \mathrm{C}\right)$ into Y block $(13 \mathrm{~mm})$ ingots following the ASTM A 536-84 standard. Three melts were prepared with $\mathrm{Cu}$ and with both, $\mathrm{Cu}+\mathrm{Ni}$ additions. The results of the chemical composition of the experimental ductile irons were carried out using a SPECTRAMAXx emission spectrometer with spark excitation as shown in Table 1.

The implemented heat treatments consisted of: (a) Austenitizing in a silite furnace at $1173 \mathrm{~K}\left(900 \pm 2{ }^{\circ} \mathrm{C}\right)$ for $30 \mathrm{~min}$, (b) austempering in a salt bath of $\mathrm{NaNO}_{2}-\mathrm{KNO}_{3}$ at $653 \mathrm{~K}$ $\left(380 \pm 2{ }^{\circ} \mathrm{C}\right.$ ) for up to $2 \mathrm{~h}$, and (c) air cooling to room temperature. As regards the austempering cycle for the following conditions: (a) after incubation times, (b) at maximum transition rate times, (c) at $600 \mathrm{~s}$ austempering time, interrupting the isothermal transformation was preceded by rapid cooling of samples in water. The dilatometric studies were performed using the DI-105 absolute dilatometer. In this case, samples were austenitized at $1173 \mathrm{~K}\left(900 \pm 1{ }^{\circ} \mathrm{C}\right)$ for $30 \mathrm{~min}$, (b) austempering in a salt bath of $\mathrm{NaNO}_{2}-\mathrm{KNO}_{3}$ at $653 \mathrm{~K}$ $\left(380 \pm 1{ }^{\circ} \mathrm{C}\right.$ ) for $2 \mathrm{~h}$. An average cooling rate from austenitizing to an isothermal austempering was $20^{\circ} \mathrm{C} / \mathrm{s}$. In addition, Vickers hardness measurements were made using a HPO-250 hardness tester, while a JEOL JSM-5500LV scanning electron microscope (SEM) was employed for metallographic characterization and for observations of the graphite morphology. Metallographic determination of the volume fraction of ferrite was made using a Leica QWin v3.5 quantitative analyzer. The analysis was based on the use of a line scan of the measuring area. This method counts the number of ferrite plates which have been cut by the line scan. The final result was the arithmetical average of the ferrite plates fraction in the microstructure during the scan of at least ten areas of the sample. Expected value of measurement error by linear analysis is $\pm 5 \%$ (for number of particles taken into account in experiment). In addition an x-ray diffraction was used to determine volume fraction of austenite. The D500 Kristalloflex (Siemens) was used with $\mathrm{Cu} \mathrm{K}$ a radiation at $40 \mathrm{kV}$ and $40 \mathrm{~mA}$ and with step scan at $0.02^{\circ}$ in the $2 \theta$ range of $25^{\circ}$ to $125^{\circ}$.

\section{Results and Discussion}

The kinetics of the austempering transformation was followed by dilatometric means (Ref 1-4). The method is based on determinations of the relative expansion of the material under investigation as a function of time and temperature. The exponential equation given below was used for describing the isothermal transformation processes:

$f=\exp (-1 / n t)$

where $f$ is the volume fraction of the transformation product and $n$ is a curve-shape constant valid for a given transformation condition. Figure 1(a) shows dilatometric curves indicating the degree of transformation $(f)$ as a function of the austempering time $(t)$ in the investigated alloys. Figure 1(b) shows first derivatives of the dilatometric curves (Fig. 1a) with respect to time indicating transformation rates. From these results, quantitative parameters describing the austempering transformation kinetics were determined and they are given in Table 2. In addition, metallographic examinations, as well as Vickers hardness measurements (see Table 3) were carried out in alloys $\mathrm{A}, \mathrm{B}$, and $\mathrm{C}$ after isothermal austempering for the following conditions: (a) After incubation times, (b) at maximum transition rate times, (c) at $600 \mathrm{~s}$ austempering time, and (d) after full austempering transformation times (see Table 2). Figures 2(a)-(c) are SEM micrographs of the exhibited austempered microstructures, while Table 3 gives the hardness measurement results.

It is well known (Ref 17, 21-23) that the austempering transformation is closely related to the nucleation and growth of ferrite plates in the austenite matrix during isothermal austempering. The transformation occurs in a temperature range above that for active diffusionless martensitic transformations, but below the one that promotes the diffusive transformation of austenite into ferrite and pearlite. Moreover, the transformation kinetics is strongly influenced by (a) the chemical composition of base iron, (b) graphite shape and size, and (c) austenitizing and austempering temperatures. Although there have been numerous studies in this field (Ref 19-21), the actual mechanism for an ausferrite reaction has not yet been fully disclosed. Among these controversies are the models proposed for the initial growth of ferrite plates. There are two entirely opposite views (Ref 16-21), diffusional versus diffusionless ferrite growth. In the diffusional model, the ausferrite plates are assumed to evolve by a carbon diffusion into the surrounding austentite matrix (Ref 4, 18-21). In contrast, it is suggested that the ausferrite transformation is diffusionless as far as substitutional atoms are concerned (Ref 17, 21). Apparently, the

Table 1 Chemical composition of the investigated ductile irons

\begin{tabular}{|c|c|c|c|c|c|c|c|c|}
\hline Alloy & $\mathrm{C} \%$ & $\mathrm{Si} \%$ & Mn\% & P\% & S\% & Mg\% & $\mathrm{Cu} \%$ & Ni\% \\
\hline A & 3.64 & 2.70 & 0.39 & 0.03 & 0.01 & 0.040 & 0.01 & 0.03 \\
\hline B & 3.65 & 2.65 & 0.30 & 0.03 & 0.01 & 0.045 & 0.99 & 0.04 \\
\hline $\mathrm{C}$ & 3.61 & 2.70 & 0.40 & 0.03 & 0.01 & 0.050 & 0.95 & 1.10 \\
\hline
\end{tabular}



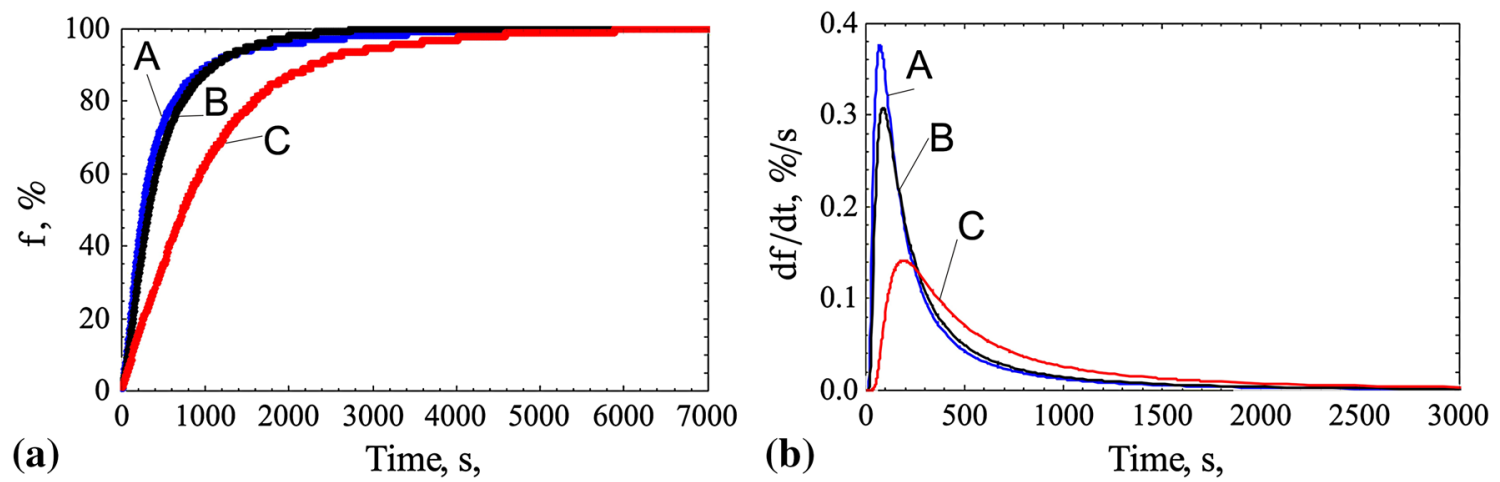

Fig. 1 Austempering transformation kinetics: (a) transformed volume fractions and (b) transformation rates. Curves: blue-alloy A, black-alloy $\mathrm{B}$, red-alloy $\mathrm{C}$

Table 2 Kinetic parameters for the ausferritic transformation

\begin{tabular}{|c|c|c|c|c|c|}
\hline Alloy & $\begin{array}{l}\text { Incubation } \\
\text { time, } t_{i \mathrm{~A}}(\mathrm{~s})\end{array}$ & $\begin{array}{c}\text { Austempering } \\
\text { transformation } \\
\text { time, } t_{\mathrm{A}}(\mathrm{s})\end{array}$ & $\begin{array}{c}\text { Parameter } \\
n, \times 10^{3}(\text { Eq 1) }\end{array}$ & $\begin{array}{l}\text { Max. transition } \\
\text { rate, } \mathrm{d} f / \mathrm{d} t(\% / \mathrm{s})\end{array}$ & $\begin{array}{c}\text { Time for maximum } \\
\text { transition rate, } t_{i-\max }(\mathrm{s})\end{array}$ \\
\hline A & 41 & 5535 & 6.94 & 0.37 & 70 \\
\hline B & 43 & 5405 & 5.68 & 0.31 & 88 \\
\hline $\mathrm{C}$ & 110 & 6000 & 2.61 & 0.14 & 192 \\
\hline
\end{tabular}

Table 3 Exhibited hardness for A, B and C alloys after characteristic austempering times

\begin{tabular}{lcc}
\hline Sample & Austempering time, $\mathbf{S}$ & Hardness, HV30 \\
\hline \multirow{2}{*}{ A } & $t_{i \mathrm{~A}+30}$ & 670 \\
& $t_{i \text {-max }}$ & 575 \\
& 600 & 381 \\
$\mathrm{~B}$ & $t_{\mathrm{A}}$ & 330 \\
& $t_{i \mathrm{~A}+30}$ & 670 \\
& $t_{i \text {-max }}$ & 631 \\
& 600 & 429 \\
$\mathrm{C}$ & $t_{\mathrm{A}}$ & 331 \\
& $t_{i \mathrm{~A}+30}$ & 657 \\
& $t_{i-\max }$ & 572 \\
& 600 & 563 \\
& $t_{\mathrm{A}}$ & 308 \\
\hline
\end{tabular}

existing controversies are directly related to the intrinsic complexities of the transformation mechanism, including a wide range of exhibited microstructures (Ref 22).

From the dilatometric studies it is found that $\mathrm{Cu}$ additions alone (alloy B) do not have a significant effect on the incubation times in contrast to the combination of $\mathrm{Cu}$ and $\mathrm{Ni}$ (alloy C). Apparently, when both elements are involved, the exhibited incubation times for the austempering transformation increase more than twofold. Metallographic observations (from a viewpoint of number of ferrite plates, see Fig. 2a) and hardness measurements (showing similar HV30 hardness values at time $t_{i \mathrm{~A}+30}$, see Table 3 ) also confirm this effect. Also, notice that just after the incubation time, there are a few visible thin ferrite plates (Fig. 2a) on the background of the metastable austenitic (A, B, and C alloys), which partly transforms to martensite. In turn, the presence of these thin ferrite plates can be attributed to a diffusionless nucleation mechanism at the onset of the austempering transformation. Austenite stability increases with passage of time until the aforementioned range of $1.8-2.2 \%$ of $\mathrm{C}$ is reached at a full time of austempering. Then in microstructure occurs only stable austenite (which does not transform to martensite) and ferrite plates.

The maximum number of developed ferrite plates was found to occur in alloy $\mathrm{B}$ suggesting that $\mathrm{Cu}$ additions promote the formation (nucleation) of new ferrite plates. In alloy $\mathrm{C}$ (in contrast with alloys A and B) there is a slight drop in hardness that can be attributed to the influence of $\mathrm{Ni}$ on the $M_{\mathrm{s}}$ (martensite start) temperature, which is expected to reduce the fraction of martensite. Moreover, the initially formed thin ferrite plates are found to significantly thicken over time probably as a result of a diffusional transformation of austenite to ferrite. At the same time, new ferrite plates develop by a diffusionless mechanism. In the initial stage of this austempering transformation (up to its maximum value), the addition of copper, and even to a greater extent, both copper and nickel reduces its rate and moves the maximum value to the right (Fig. 1b). This effect can be explained by the role of $\mathrm{Ni}$ and $\mathrm{Cu}$ on restraining the diffusional growth of ferrite plates by hindering the carbon diffusion into the surrounding austenite. Another important factor influencing the kinetics of the austempering transformation is the synergetic effect of both $\mathrm{Ni}$ and $\mathrm{Cu}$ elements on the ferrite plate nucleation tendency.

Although, $\mathrm{Cu}$ has a strong effect on reducing C-diffusivity in the matrix, this effect is negligible when compared with its positive effect on the nucleation of new ferrite plates for times beyond the ones corresponding to the maximum transformation rates (alloy B). Apparently, during the second austempering stage once the maximum rate has been exceeded, the dominant effect of $\mathrm{Cu}$ is in hastening the transformation rates and consequently in promoting the refinement of the ausferrite formed in alloy B. The outcome of this work suggests that the 
A

(a)

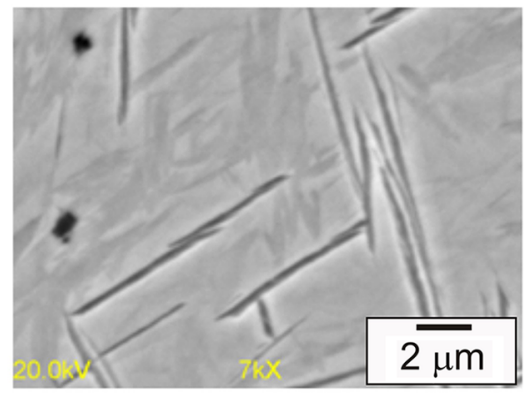

(b)

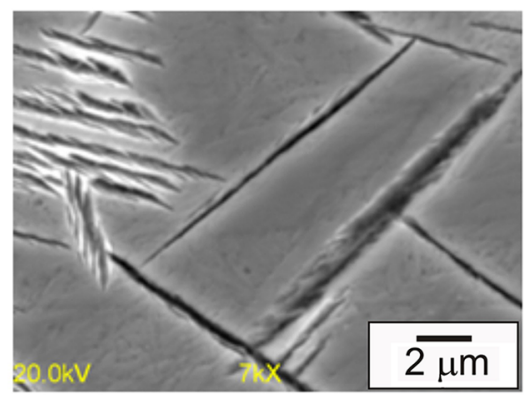

(c)

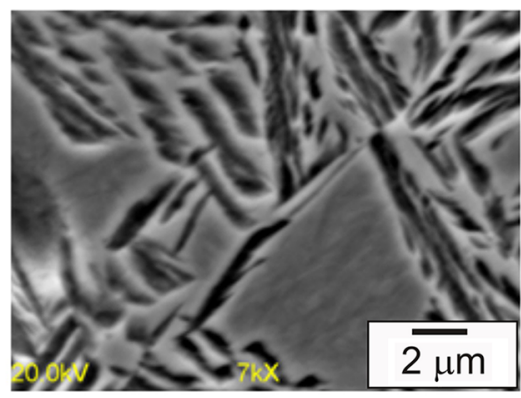

(d)

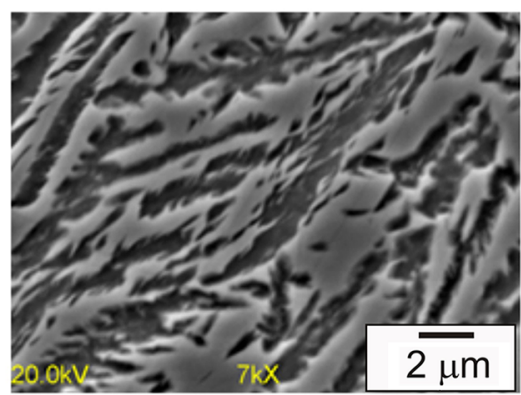

B
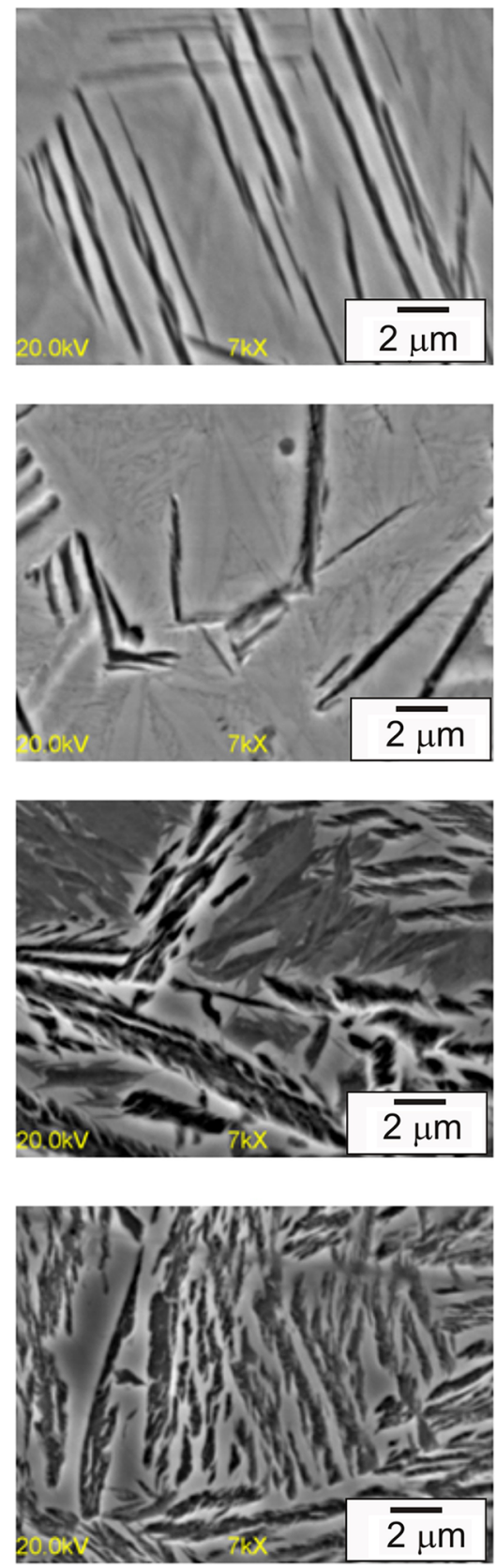

C
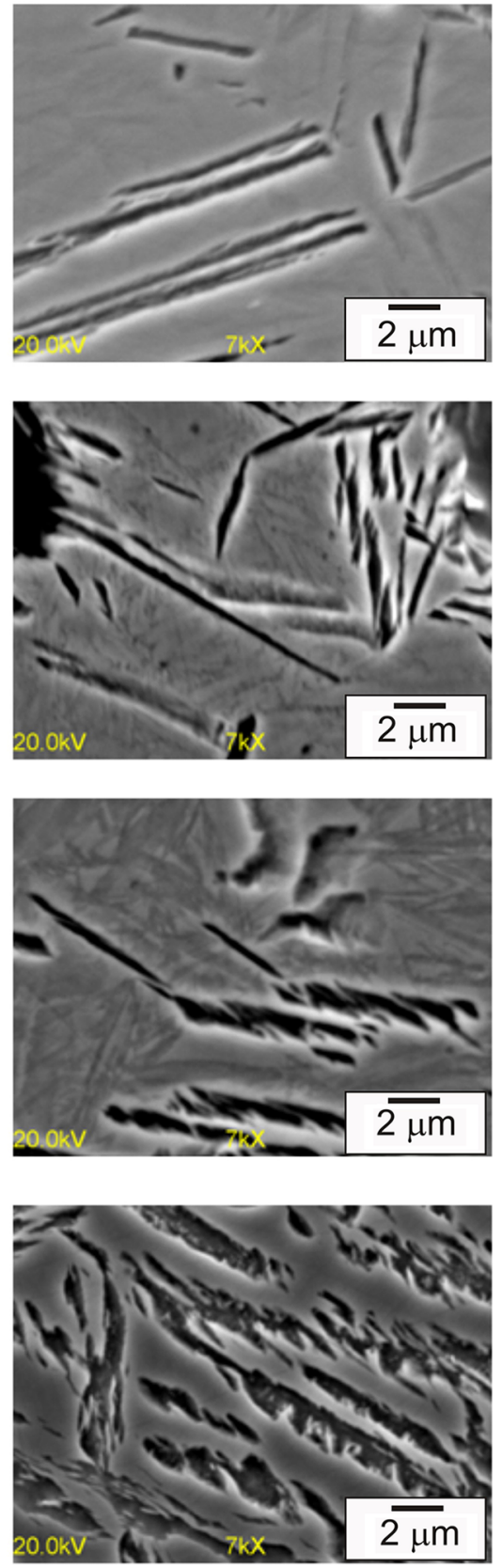

Fig. 2 Exhibited microstructures for the investigated alloys A, B, and C: (a) just after the incubation times, (b) at maximum transition rate times, (c) at $600 \mathrm{~s}$ of austempering, and (d) after full austempering transformation time

maximum reached on the transformation rate curves (Fig. 1b) can be considered as the time beyond which the growth of ferrite plates become predominant by diffusion-controlled mechanisms. Accordingly, during this stage, the transformation rate is determined by carbon diffusion into the austenite phase.

When both, $\mathrm{Cu}$ and $\mathrm{Ni}$ are present in the ADI (alloy $\mathrm{C}$ ) the times needed for a full austempering transformation become the largest (see Fig. 1). Apparently, $\mathrm{Cu}$ in combination with $\mathrm{Ni}$ have the strongest effect on reducing the transformation rates through their effect on the formation of new ferrite plates. Besides the effect on the ausferrite morphology, $\mathrm{Cu}$ and $\mathrm{Ni}$ additions also affect the volume fractions of the exhibited phase components after completion of the austempering process. From quantitative metallographic determinations, it is found that the volume fraction of ferrite in alloys $\mathrm{A}, \mathrm{B}$, and $\mathrm{C}$ is 54 , 48 , and $42 \%$, respectively. This is confirmed by XRD investigations. In Figure 3, diffraction patterns for alloy B along with austenite fraction are shown. Notice the reduction in the fraction of ferrite with the addition of $\mathrm{Cu}$ and $\mathrm{Cu}$ plus $\mathrm{Ni}$ as a result of an additional $\mathrm{C}$ enriched stable austenite effect.

XRD investigations took into account austempering time according to Table 3 . In sample taken just after the incubation time $\left(t_{i \mathrm{~A}+30}\right)$ austenite fraction amount $16 \%$ and increases up to $47 \%$ for sample after full austempering treatment $\left(t_{\mathrm{A}}\right)$.

Figure 4 is a schematic diagram of the proposed transformation mechanism and rates including the number of nucleated ferrite plates. This figure also shows a plausible sequence for the microstructural evolution during austempering. 


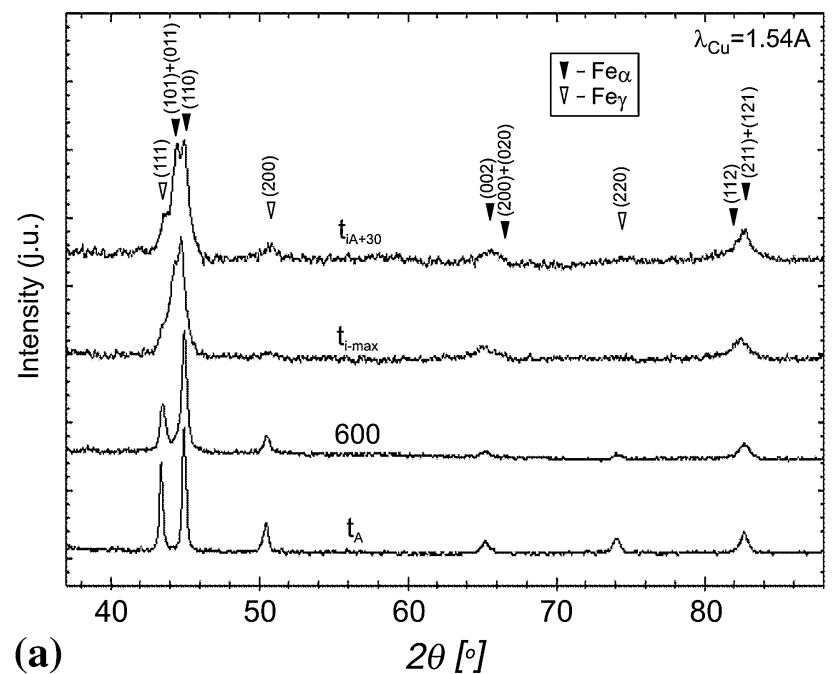

\begin{tabular}{|c|c|}
\hline $\begin{array}{c}\text { Austempering } \\
\text { time, } \mathrm{s}\end{array}$ & $\begin{array}{c}\text { Volume fraction of } \\
\text { austenite [\%] }\end{array}$ \\
\hline $\mathrm{t}_{\mathrm{iA}+30}$ & 16.13 \\
\hline $\mathrm{t}_{\mathrm{i}-\max }$ & 20.26 \\
\hline 600 & 38.23 \\
\hline $\mathrm{t}_{\mathrm{A}}$ & 47.12 \\
\hline
\end{tabular}

(b)

Fig. 3 Superimposed XRD plots for alloy B (a), volume fraction of austenite (b) after characteristic austempering times

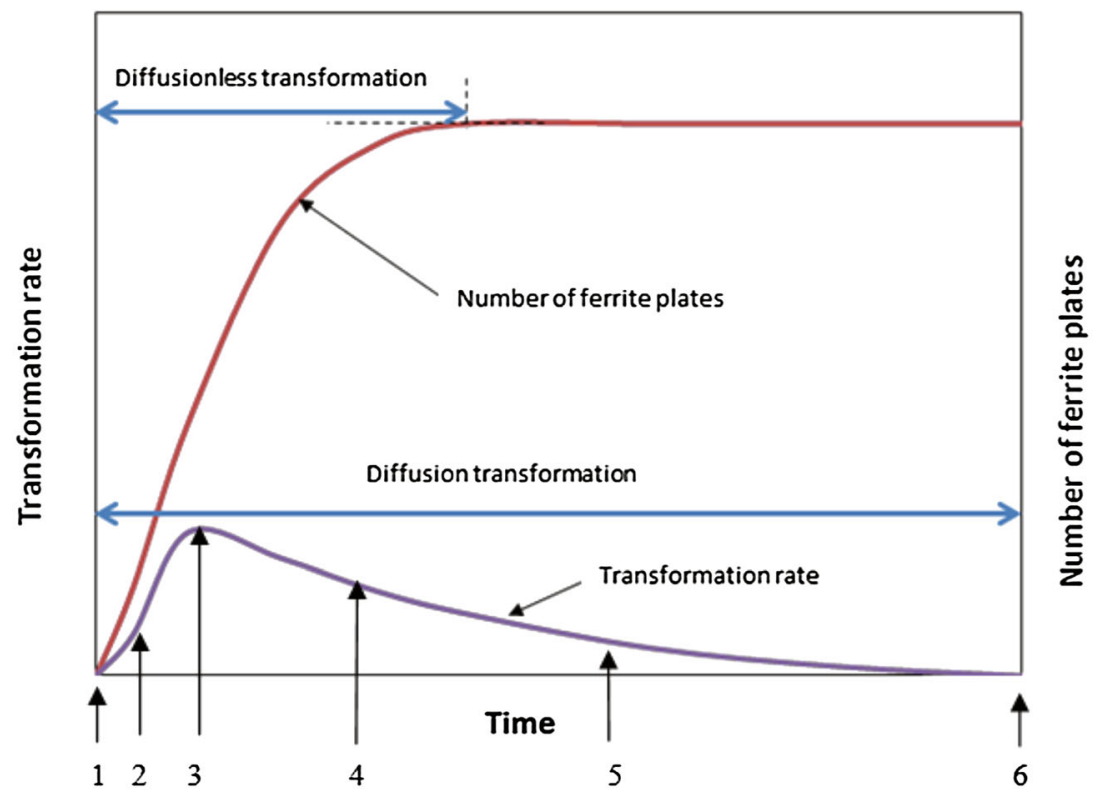

(a)

123

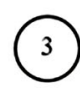

(4)

(5)

6
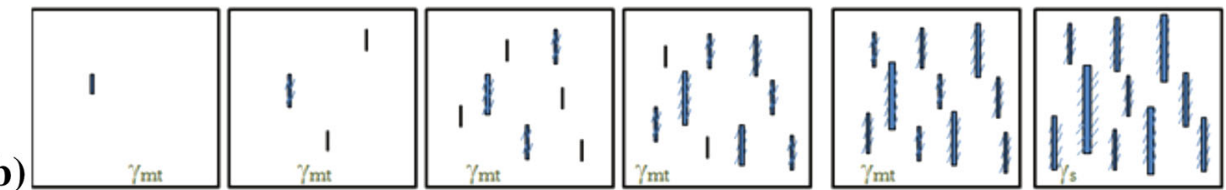

Fig. 4 Schematic illustration of (a) transformation rates and number of formed ferrite plates and (b) ferrite plates formation sequence during the austempering transformation. | Diffusionless nucleation of ferrite plates, diffusional growth of ferrite plate, $\gamma_{\mathrm{mt}}$ metastable austenite (which partly transforms to martensite), $\gamma_{\mathrm{s}}$ stable austenite

The sequence of formation of ferrite plates is given by numbers 1 to 6 in Fig. 4. In this figure, it can be observed that the austempering transformation begins with the developing ferrite plates by a diffusionless mechanism (1) against the metastable austenite $\gamma_{\mathrm{mt}}$ (which partly transforms to martensite), and their largest plate density corresponds to the maximum transformation rate (3). The diffusionless formation of ferrite plates is followed by diffusional growth (2-6), giving rise to a continuous change in transformation rates during austempering. After reaching the maximum transformation rates (4), the growth of ferrite plates becomes predominant by diffusion-controlled mechanism during the transformation at rates that are determined by the actual diffusivity of carbon in austenite. Upon completion of the nucleation stage for ferrite plates (5) further 
growth is diffusion controlled and leads to the development of stable austenite $\gamma_{\mathrm{s}}(6)$.

\section{Conclusions}

1. Dilatometric studies indicate that the addition of $\mathrm{Cu}$ (alloy B) does not have a significant effect on the incubation times for the austempering transformation. The austempering process is characterized by different transformation rates (see Fig. 1b). In the initial stage, the addition of $\mathrm{Cu}$ and to a greater extent $\mathrm{Cu}$ combined with $\mathrm{Ni}$ additions has a marked effect on reducing the transformation rates.

2. The outcome of this work indicates that the initial nucleation of ferrite plates occurs by a diffusionless mechanism. Also, the maximum transformation rate (Fig. 1b) is the time beyond which predominant ferrite plate growth takes place by diffusion. In the second stage for the austempering transformation (from about 50\% transformation), $\mathrm{Cu}$ additions promote the transformation rates significantly reducing transformation times.

3. When both copper and nickel are added, the transformation times become the largest. In turn this leads to the lowest transformation rates during the initial transformation stage.

4. A qualitative model is proposed which can describe the sequence of ferrite plate formation during the austempering transformation. The model assumes that the ferrite phases are nucleated by a diffusionless mechanism while their growth rate is limited by carbon diffusion into the surrounding austenite phase.

\section{Open Access}

This article is distributed under the terms of the Creative Commons Attribution License which permits any use, distribution, and reproduction in any medium, provided the original author(s) and the source are credited.

\section{References}

1. M.M. Cisneros-Guerrero, R.E. Campos-Cambranis, M. Castro-Román, and M.J. Pérez-López, Austempering Kinetics in $\mathrm{Cu}-\mathrm{Mo}$ Alloyed Ductile Iron: A Dilatometric Study, Adv. Mater. Res., 1997, 4-5, p 415-420

2. E. Fraś, M. Górny, E. Tyrała, and H.F. Lopez, Effect of Nodule Count on Austenitizing and Austempering Kinetics of Ductile Iron Castings and Mechanical Properties of Thin-Walled Iron Castings, Mater. Sci. Technol., 2012, 28(12), p 1391-1396

3. M.N. Ahmadabadi and S. Farjami, Transformation Kinetics of Unalloyed and High Mn Austempered Ductile Iron, Mater. Sci. Technol., 2003, 19, p 645-649

4. M.C. Leijten, H. Nieswaag, and L. Katgerman, The Isothermal Transformation of Ductile Cast Iron, Adv. Mater. Res., 1997, 4-5, p 385-390

5. C.R. Loper, Cast Irons: Essential Alloys for the Future, Proceedings of the 65th World Foundry Congress. Gyeongju, Korea, 2002, p 169-179

6. D.M. Stefanescu, Lightweight Iron Castings: Can They Replace Aluminum Castings? Foundryman, 2003, p 221-224

7. J.F. Janowak and R.B. Gundlach, Development of a Ductile Iron for Commercial Austempering, AFS Trans., 1983, 91, p 377-388

8. D.J. Moore, T.N. Rouns, and K.B. Rundma, Effect of Manganese on Structure and Properties of Austempered Ductile Iron: A Processing Window Concept, AFS Trans., 1986, 94, p 255-264

9. N. Darwish and R. Eliott, Austempering of Low Manganese Ductile Irons: Part 1 Processing Window, Mater. Sci. Technol., 1993, 9, p 572-585

10. W.S. Owen, The Effect of Silicon on the Kinetics of Tempering, AIME Trans., 1954, 46, p 812-829

11. L. Tsukatani, S. Hashimo, and T. Inoue, Effects of Silicon and Manganese Addition on Mechanical Properties of High-Strength HotRolled Sheet Steel Containing Retained Austenite, ISIJ Int., 1991, 31(9), p 992-1000

12. H.K. Bhadeshia and J.W. Christian, Bainite in Steels, Metall. Trans., 1990, 21A, p 767-797

13. J. Mallia and M. Grech, Effect of Silicon Content on Impact Properties of Austempered Ductile Iron, J. Mater. Sci. Technol., 1997, 13, p 408-414

14. R.C. Voigt, Austempered Ductile Iron: Processing and Properties, Cast Met., 1989, 2, p 72-93

15. M.A. Yescas, H.K. Bhadeshia, and D.J. McKay, Estimation of the Amount of Retained Austenite in Austempered Ductile Irons Using Neural Networks, Mater. Sci. Eng., 2001, 311, p 162-173

16. B. Bosnjak, B. Radulovic, K. Pop-Tonev, and V. Asanovic, Microstructural and Mechanical Characteristics of Low Alloyed Ni-Mo-Cu Austempered Ductile Iron, ISIJ Int., 2000, 40(12), p 1246-1252

17. L. Meier, M. Hofmann, P. Saal, W. Volk, and H. Hoffmann, In Situ Measurement of Phase Transformation Kinetics in Austempered Ductile Iron, Mater. Charact., 2013, 85, p 124-133

18. F. Hellal, J. Lacaze, and A. Hazotee, Initial Stage of Isothermal Decomposition of Austenite to Ferrite and Graphite in Spheroidal Graphite Cast Iron, Mater. Sci. Technol., 1999, 15, p 773-778

19. H.I. Aaronson, W.T. Reynolds, G.J. Shiflet, and G. Spanos, Bainite Viewed Three Different Ways, Metall. Trans., 1990, 21A, p 1343-1380

20. H.I. Aaronson, T. Furuhara, J.M. Rigsbee, W.T. Reynolds, Jr., and J.M. Howe, Crystallographic and Mechanistic Aspects of Growth by Shear and by Diffusional Processes, Metall. Trans. A, 1990, 21A, p 2369-2409

21. W.T. Reynolds, Jr., H.I. Aaronson, and G. Spanos, A Summary of the Present Diffusionist Views on Bainite, Mater. Trans., 1991, 32(8), p 737-746

22. A.K. Sinha, Physical Metallurgy Handbook, McGraw-Hill, New York, 2003

23. M.M. Cisneros, M.J. Perez, R.E. Campos, and E. Valdes, The Role of $\mathrm{Cu}$, Mo and $\mathrm{Ni}$ on the Kinetics of the Bainitic Reaction During the Austempering of Ductile Irons, Int. J. Cast Met. Res., 1999, 11, p $425-430$ 